\title{
LE்TINIS SISTEMINIS UŽDEGIMAS IR KOGNITYVINIŲ FUNKCIJŲ SILPNĖJIMAS - PAVOJUS DARBOVIETEI IR DARBUOTOJŲ SVEIKATAI
}

\author{
Kamilė Počepavičiūtė ${ }^{1}$, Iveta Mykolaityte் ${ }^{2}$ \\ ${ }^{1}$ Lietuvos sveikatos mokslu universitetas, Medicinos akademija, Medicinos fakultetas, \\ ${ }^{2}$ Lietuvos sveikatos mokslu universitetas, Medicinos akademija, \\ Visuomenes sveikatos fakultetas, Aplinkos ir darbo medicinos katedra
}

\begin{abstract}
Raktažodžiai: kognityvinès funkcijos, lètinis sisteminis uždegimas, citokinai, darbo aplinka.
\end{abstract}

\begin{abstract}
Santrauka
Kognityvinès funkcijos yra svarbios ne tik kasdieniame, bet ir darbiniame gyvenime. Jų silpnejjimas siejamas su lètiniu uždegiminiu atsaku, sukeliamu ịvairių lètinių ligų, kurių rizikos veiksnių randama ir darbo aplinkoje. Tyrimo tikslas - remiantis naujausiomis mokslinèmis publikacijomis apžvelgti su lètiniu uždegimu susijusius rizikos veiksnius, esančius profesinèje aplinkoje, bei jų įtaką darbuotojų kognityvinèms funkcijoms ir darbinei veiklai. Išanalizuota 15 ne senesnių nei dešimties metu senumo publikacijų aptariama tema. Straipsniai atrinkti iš PubMed, UpToDate ir ScienceDirect medicininių duomenų bazių.

Remiantis rezultatais, pažinimo funkcijų silpnèjimas gali būti susijęs su darbo aplinkoje esančiais rizikos veiksniais: biologinèmis bei mineralinèmis dulkèmis, sunkiaisiais metalais, pesticidais ir kitais, galinčiais sukelti lètinị sisteminị uždegimą, progresuojantị iki neurodegeneracijos. Šių veiksnių įvertinimas labai svarbus profesiniam visavertiškumui - dèl kognityvinių funkcijų svarbos darbe šių funkcijų silpnèjimas yra žalingas ne tik darbuotojui, bet ir darbovietei. Šių funkcijų įvertinimo procesas yra sudetingas, neretai diagnostika vèlyva, todèl labai svarbi ne tik prevencija, bet ir ikiklinikinių pokyčių vertinimas.
\end{abstract}

\section{Ivadas}

Kognityvinès funkcijos yra neatsiejama kasdienio ir darbinio gyvenimo dalis. Joms sutrikus, pakinta informacijos gavimo - perdirbimo - integravimo grandinè, o išsaugoti ir atkurti informaciją darosi vis sudètingiau. Susilpnejjus pažinimo funkcijoms, sutrinka orientacija laike, vietoje ir savyje [1]. Laipsniškai silpnèjant kognityvinèms funkcijoms, labai pasunkèja darbinè veikla - ilgainiui žmogus ne tik nesugeba įsiminti naujos informacijos, bet nebepanaudoja ir turimų žinių [1,2]. Visos aukščiau minètos funkcijos yra itin svarbios kasdienejje ir darbinèje veikloje, o joms susilpnèjus, nukenčia gyvenimo kokybė bei darbo rezultatai.

Vienas svarbiausių rizikos veiksnių lengviems kognityviniams sutrikimams bei demencijoms išsivystyti yra vyresnis amžius [3]. Europos Komisija 2021 metų Žaliojoje knygoje dèl senéjimo pažymi, jog nuo 2020 m. iki 2040 m., siekiant išlaikyti pastovų senëjimo indeksą, Lietuvoje darbinis amžius turètų būti didinamas iki 72 metų [4]. Ruošiantis ịgyvendinti šias rekomendacijas, būtina suprasti sveikos darbo aplinkos svarbą, siekiant kuo ilgiau išlaikyti bendrą sveikatos lygị. Tokiu būdu būtų gaunama ir ekonominès naudos - demencijų našta, tenkanti Europos Sajungai, 2007 m. buvo įvertinta net 189 bilijonų eurų suma [5].

Pastaraisiais metais kognityvinių funkcijų silpnėjimas senstant vis dažniau siejamas su lètinio uždegimo sukeliamais pokyčiais smegenyse, pvz., vienos iš dažniausių demencijų - Alzheimerio liga ir kraujagyslinè demencija taip pat susijusios su lètiniu uždegimu [3]. Siekiant ilgesnio kokybiško darbinio amžiaus, svarbu apsvarstyti ir darbineje aplinkoje esančius rizikos veiksnius, susijusius su uždegimo grandžių aktyvavimu bei lètinèmis ligomis.

Tyrimo tikslas - remiantis naujausiomis mokslinemis publikacijomis, apžvelgti letinio sisteminio uždegimo, sukelto darbo aplinkos rizikos veiksnių, įtaką kognityvinių funkcijų silpnejjimui ir reikšmę profesinei veiklai.

\section{Tyrimo medžiaga ir metodai}

Atlikta 15 publikacijų mokslinė apžvalga. Straipsniai atrinkti naudojantis PubMed, UpToDate ir ScienceDirect duomenų bazèmis. İ apžvalgą įtrauktos ne senesnès nei dešimties metų publikacijos anglų kalba. 


\section{Tyrimo rezultatai}

Lètinio uždegimo patogenezė. Nors uždegimas yra natūrali apsauginè organizmo reakcija, šiam procesui užtrukus, cirkuliuojantys citokinai gali tapti žalingi ir pažeisti visus audinius bei organus, įskaitant smegenis [3]. Siekiant išsiaiškinti lètinio uždegimo ir kognityvinių funkcijų silpnejjimo ryši, svarbu suprasti pagrindines lètinio uždegimo priežastis.

Organizme, siekiant išlaikyti imuninę pusiausvyrą, cirkuliuoja dviejų tipų citokinai: uždegimą sukeliantieji (pvz., IL-1, IL-6, TNF-alfa) ir ji slopinantieji (pvz., IL-4, IL-10) [6]. Nors in vitro citokinai gali veikti vieni, in vivo jie veikia sinergistiškai ir antagonistiškai, sudarydami nenutrūkstamą imunotinklą, palaikantị organizmo imuninę homeostazę [7].

Didejantis santykinis uždegimą sukeliančių citokinų kiekis organizme senstant gali būti susijęs ir su modifikuojamais, ir su nemodifikuojamais rizikos veiksniais. Remiantis tyrimais, senstant, tačiau nesant kitos gretutinès patologijos, galinčios turèti ịtakos imuniniam disbalansui, didèja serumo IL-6 koncentracija kraujyje [6]. Pagrindinị vaidmeni aktyvinant uždegimą sukeliančių citokinų sintezę šiuo atveju atlieka NF-кB, baltymų komplekso, kontroliuojančio citokinų sintezę, kelias [8,9]. Uždegimą sukeliančių citokinų kiekis, padidèjęs ne tik dèl lètinių, bet ir ūminių būklių, senstant nebegrịžta ị prieš ligą buvusị lygị - prasideda lètinis uždegimas. Pagrindinè problema, jog šie uždegimo mediatoriai, nepaisant cirkuliacijos periferijoje, lengvai pereina kraujo - smegenų barjerą bei moduliuoja ir centrinius uždegiminius procesus smegenyse, aktyvinančius neurodegeneraciją [6].

Lètinis uždegimas siejamas ir su kitais, modifikuojamais, veiksniais. Sisteminio lètinio uždegimo priežastis gali būti lètinès ligos, pvz., lètinè obstrukcinè plaučių liga (LOPL), cukrinis diabetas (CD) ir kitos [3].

Lètinès uždegiminès ligos darbo aplinkoje. Lètinès ligos, kurios, kaip jau minèta, siejamos su lètiniu uždegimu, galinčiu turèti ịtakos kognityvinių funkcijų silpnèjimui, gali būti sukeltos darbe esančių rizikos veiksnių. Aptarsime kelis iš jų.

Išanalizavus sergančiujų LOPL populiaciją, tyrimų duomenys parode, jog net 15 proc. ligos atvejų buvo susiję su darbo aplinkoje esančiais rizikos veiksniais. Padidejusi rizika sirgti šia liga nustatyta dirbant aplinkoje, kurioje randama biologinių bei mineralinių dulkių, dujų ir garų [10].

N. Gianniou su bendraautoriais atliktas tyrimas atskleide, kad ugniagesių didesnè viršutinių ir apatinių kvẻpavimo takų uždegimo rizika, ypač astmos, LOPL, sinusitų. Tai siejama su medžio bei kitos biomasès degimo produktų toksiškumu. Nepaisant vietinių kvėpavimo takų reakcijų, pastebètas ir sisteminio uždegiminio atsako suaktyvèjimas, susijęs su padidejusia IL-1b, IL-6 koncentracija kraujyje, daug aktyvesnè polimorfonuklearų ir monocitų gamyba kaulų čiulpuose [11].

Lètinè intoksikacija pesticidais susijusi su oksidaciniu stresu bei lètinėmis ligomis, skatinančiomis sisteminị uždegimą $[7,12]$. Ypač didelès rizikos grupei priskiriami žemès ūkio darbininkai bei jų šeimos. Priklausomai nuo patekimo ị organizmą būdo, apsinuodijimas pesticidais gali pasireikšti ūminèmis ar lètinèmis ligomis. Lètinè šių cheminių medžiagų ekspozicija siejama su padidejjusia věžio, ypač prostatos, plaučių, kepenų, krūties bei storosios žarnos, rizika [7].

Nustatytas ryšys tarp chloro ir fosforo organiniu pesticidu bei $C D$ išsivystymo. Ištyrus išsivysčiusiose šalyse naudojamo ometoato poveikị laboratorinėms pelèms, pastebètas malondialdehido, TNF-alfa ir IL-6 koncentracijos padidejjimas jų raumenyse, skatinantis rezistentiškumo insulinui išsivystymą [7]. Remiantis tyrimais, ūkininkams, darbe susiduriantiems su fosforo organinèmis medžiagomis, nustatyta ne tik didesnè neuropsichologinių ligų (tiesioginis neurotoksinis poveikis), bet ir CD rizika, dèl kurios galimas sisteminis uždegimas, darantis ir toksinị poveikị smegenims (netiesioginis poveikis) $[12,13]$.

Svarbūs ir kiti darbo aplinkoje aptinkami toksinai. Vienas tokių pavyzdžių - švinas, žalingas daugeliui organų sistemų: kraujodaros, inkstų, kardiovaskulinei ir tiesiogiai - nervų [14]. Švino randama keramikos, ginklų pramonèje, valčiu statybos, langų gamybos, leidybos įmonèse [15]. Molekuliniai toksiškumo mechanizmai vis dar nèra galutinai ištirti, tačiau švinui jungiantis prie baltymų, natūraliai jungiančių kalcio, cinko jonus, išreguliuojamos cheminès grandinès ląstelëje, moduliuojamas intraceliulinis signalų plitimo kelias [14]. Tyrimai rodo, jog švinas susijęs su oksidacinio streso išsivystymu, esant padidèjusiai reaktyvių deguonies formų (ROS) gamybai, arba sumažejus jų šalinimui. ROS atsakingi aktyvuojant mitogenais aktyvinamas baltymų kinazes (MAPK) ir branduolio faktorių kappa B, kurie svarbūs uždegimą skatinančių molekulių sintezejje. Tyrimuose su laboratorinèmis pelèmis pastebèta, jog švinas didina TNF-alfa, IL-1beta, IL-6 koncentracijas, ypač didèjant IL-1 ekspresijai pelių smegenu žieveje ir hipokampe $[14,15]$. Nustatyta teigiama koreliacija tarp švino ekspozicijos aplinkoje ir kitų lètinių (kardiovaskulinių) ligų, ypač arterinès hipertenzijos, išsivystymo [14].

Kognityvinių funkcijų svarba darbinẻje veikloje. Šiuolaikinè darbovietė yra labai priklausoma nuo darbuotojų kognityvinių gebẻjimų. Literatūroje aprašomi du modeliai, kuriais analizuojami kognityviniai gebejjimai, svarbūs dirbant. Vienas modelis koncentruojamas ị darbo pozicijos poreikius (profesijos klasifikuojamos pagal sukuriamą produktą ir atliekamus procesus), kitas siūlo darbininkus vertinti kognityvinių funkcijų testais, testų rezultatus lyginant su darbo rezultatais [2].

L. Pool su kolegomis detaliai aptare kognityvines funkcijas, reikalingas darbinėje aplinkoje. Apžvelgdami O*NET (angl. the Department of Labor's Occupational Information 
Network) duomenų rinkimo projekto rezultatus, jie išskyrẻ dešimtị darbo veiklų, reikalaujančių kognityvinių funkcijų panaudojimo: daiktų, paslaugų ar žmonių savybių įvertinimas; informacijos palyginimas su normomis; informacijos apdorojimas; duomenų ar informacijos nagrinejimas; problemų sprendimas ar sprendimų priemimas; kūrybinis mąstymas; darbe aktualių žinių panaudojimas ir atnaujinimas; darbo tikslų išsikèlimas bei strategijų kūrimas; darbų ir veiklos tvarkaraščio sudarymas; organizavimas, planavimas ir pirmenybès teikimas [16]. Šie mokslininkai profesinių kognityvinių reikalavimų balu (angl. Occupational cognitive requirements score) pagal anksčiau minètų pažinimo funkcijų panaudojimo svarbą bei dažnį tam tikrose veiklose ịvardijo jų panaudojimo poreikị skirtingose profesinèse veiklose. Daugiausia kognityvinių funkcijų reikalauja specialistų bei vadovaujamasis darbas, mažiausiai - fizinis darbas $[10,16]$.

Reikia paminèti, jog kognityvinès funkcijos nelaikomos tik priemone, jos darbo metu užsiimant tam tikra veikla neabejotinai yra ugdomos, todèl skirtingoms darbuotojų populiacijoms tie patys darbo aplinkos rizikos veiksniai gali būti susiję su skirtinga baigtimi [17].

Lètinio uždegimo įtaka kognityvinėms funkcijoms. Uždegiminiai citokinai nevienodai veikia visas smegenis ir yra labiau susiję su tam tikrų smegenų funkcijų susilpnèjimu bei praradimu. Molekuliniu lygmeniu ištyrus smegenis, paaiškejjo, jog nepaisant didelès uždegiminių citokinų raiškos astroglijoje ir mikroglijoje, visuose smegenų neuronuose bei endotelio ląstelèse, santykinai daugiausia jų nustatyta smegenų žievejje ir hipokampe. Pastarojoje struktūroje citokinų raiška ir morfologiniai pokyčiai stebèti ryškiausi $[6,18]$. Lyginant su kitomis sritis, limbinėje sistemoje bei kitose su kognityvinemis funkcijomis susijusiose anatominèse struktūrose (pvz., pamato branduoliuose) stebèti daug aktyvesni uždegiminiai procesai. Tai rodo, jog lètiniam uždegimui jautriausios būtent kognityvinès funkcijos [6].

Kliniškai ịvertinti kognityvines funkcijas ir patologinius jų pokyčius sudètinga. Net ir esant morfologinių pokyčių smegenyse, kliniškai kognityvinių funkcijų susilpnèjimas gali nepasireikšti [17]. Dèl šios priežasties stengiamasi vertinti dar ikiklinikinius kognityvinių funkcijų silpnėjimo pokyčius. İvertinus uždegiminių citokinų (IL-6, TNF-alfa) koncentracijas kraujyje ir palyginus su modifikuoto Mini Mental testo rezultatais pastebèta, jog IL-6 koncentracijos padidejjimas susijęs su pažinimo funkcijų silpnèjimu ateityje, dvejų metų laikotarpyje [3].

\section{Išvados}

1. Lètinès uždegiminès ligos susijusios su lètiniu sisteminiu uždegimu, galinčiu sukelti neurodegeneraciją, o kartu ir kognityvinių funkcijų silpnèjimą.
2. Lètinis uždegiminis atsakas gali būti susijęs su darbo aplinkoje esančiais rizikos veiksniais, pvz., biologinėmis ar mineralinėmis dulkèmis, cheminèmis medžiagomis (pesticidais, sunkiaisiais metalais ir kitomis).

3. Kognityvinès funkcijos svarbios ne tik kasdieneje, bet ir darbinejje veikloje, jų silpnejjimas - praradimas ne tik darbuotojui, bet ir darbovietei.

4. Kognityvinių funkcijų silpnèjimo diagnostika sudètinga ir neretai uždelsiama, todèl labai svarbi dar ikiklinikinių pokyčių stebèsena.

\section{Literatūra}

1. Arnoriaga-Rodriguez M, Fernandez-Real JM. Microbiota impacts on chronic inflammation and metabolic syndrome - related cognitive dysfunction. Rev Endocr Metab Disord 2019;20:473-80.

https://doi.org/ 0.1007/s11154-019-09537-5

2. Hunt E, Madhyastha TM. Cognitive demands of the workplace. J Neurosci Psychol Econ 2012;5(1):18-37.

https://doi.org/10.1037/a0026177

3. Sartori AC, Vance DE, Slater LZ, Crowe M. The impact of inflammation on cognitive function in older adults: Implications for healthcare practice and research. J Neurosci Nurs 2012;44(4):206-17.

https://doi.org/10.1097/JNN.0b013e3182527690

4. European Comission. Green Paper on Ageing. Fostering solidarity and responsibility between generations. Brussels 2021. https://ec.europa.eu/info/sites/default/files/1_en_act_part1_ v8_0.pdf

5. Then FS, Luck T, Luppa M, Thinschmidt M, Deckert S, Nieuwenhuijsen K, et al. Systematic review of the effect of the psychosocial working environment on cognition and dementia. Occup Environ Med 2014;71(5):358-65.

http://doi.org/10.1136/oemed-2013-101760

6. Marsland AL, Gianaros PJ, Kuan DCH, Sheu LK, Krajina K, Manuck SB. Brain morphology links systemic inflammation to cognitive function in midlife adults. Brain Behav Immun 2015;48(412):195-204.

https://doi.org/10.1016/j.bbi.2015.03.015

7. Gangemi S, Gofita E, Costa C, Teodoro M, Briguglio G, Nikitovic D, et al. Occupational and environmental exposure to pesticides and cytokine pathways in chronic diseases (Review). Int J Mol Med 2016;38(4):1012-20.

https://doi.org/ 10.3892/ijmm.2016.2728

8. Chung HY, Kim DH, Lee EK, Chung KW, Chung S, Lee B, et al. Redefining chronic inflammation in aging and age-related diseases: proposal of the senoinflammation concept. Aging Dis 2019;10(2):367-82.

https://doi.org/ 10.14336/AD.2018.0324

9. Liu T, Zhang L, Joo D, Sun SC. NF-kB signaling in inflammation. Signal Transduct Target Ther 2017;2. 
https://doi.org/10.1038/sigtrans.2017.23

10. Omland Ø, Würtz ET, Aasen TB, Blanc P, Brisman J, Miller $\mathrm{MR}$, et al. Occupational chronic obstructive pulmonary disease: a systematic literature review. Scand J Work Environ Heal 2014;40(1):19-35. https://doi.org/ 10.5271/sjweh.3400

11. Gianniou N, Katsaounou P, Dima E, Giannakopoulou CE, Kardara M, Saltagianni V, et al. Prolonged occupational exposure leads to allergic airway sensitization and chronic airway and systemic inflammation in professional firefighters. Respir Med 2016;118:7-14. https://doi.org/10.1016/j.rmed.2016.07.006

12. Astiz M, De Alaniz MJT, Marra CA. The oxidative damage and inflammation caused by pesticides are reverted by lipoic acid in rat brain. Neurochem Int 2012;61(7):1231-41. https://doi.org/10.1016/j.neuint.2012.09.003

13. Paul KC, Jerrett M, Ritz B. Type 2 diabetes mellitus and Alzheimer's disease: overlapping biologic mechanisms and environmental risk factors. Curr Environ Health Rep 2018;5(1):44-58. https://doi.org/10.1007/s40572-018-0176-1

14. Machoń-Grecka A, Dobrakowski M, Boroń M, Lisowska G, Kasperczyk A, Kasperczyk S. The influence of occupational chronic lead exposure on the levels of selected pro-inflammatory cytokines and angiogenic factors. Hum Exp Toxicol 2017;36(5):467-73.

https://doi.org/10.1177/0960327117703688

15. Fenga C, Gangemi S, Di Salvatore V, Falzone L, Libra M. Immunological effects of occupational exposure to lead (Review). Mol Med Rep 2017;15(5):3355-60. https://doi.org/10.3892/mmr.2017.6381

16. Pool LR, Weuve J, Wilson RS, Bültmann U, Evans DA, Mendes De Leon CF. Occupational cognitive requirements and late-life cognitive aging. Neurology 2016;86(15):1386-92.

https://doi.org/10.1212/WNL.0000000000002569
17. Opdebeeck C, Martyr A, Clare L. Cognitive reserve and cognitive function in healthy older people: a meta-analysis. Aging, Neuropsychol Cogn 2016;23(1):40-60. https://doi.org/10.1080/13825585.2015.1041450

18. Lin T, Liu GA, Perez E, Rainer RD, Febo M, Cruz-Almeida $\mathrm{Y}$, et al. Systemic inflammation mediates age-related cognitive deficits. Front Aging Neurosci 2018;10(AUG):1-9. https://doi.org/10.3389/fnagi.2018.00236

\section{CHRONIC SYSTEMIC INFLAMMATION AND COGNITIVE IMPAIRMENT - A HAZARD IN THE WORKPLACE AND THREAT TO THE HEALTH OF EMPLOYEES}

\section{K. Počepavičiūtė, I. Mykolaitytė}

Keywords: cognitive functions, chronic systemic inflammation, cytokines, workplace.

Summary

Cognitive functions are important not only in daily life, but also at work. Cognitive impairment is associated with chronic inflammatory response related to chronic diseases which risk factors are found in the workplace too.

Based on the results of this rewiev, risk factors in the workplace, such as biological and mineral substances, other chemicals as heavy metals, pesticides, can be related to chronic systemic inflammation and lead to neurodegeneration. Assessment of these factors is necessary for professional integrity and due to the importance of cognitive functions at work, impariment of these functions is detrimental not only to employees but also to employers. However, the process of assessing is complex and diagnosis of cognitive impairment is often too late, so not only prevention but also assessment of preclinical changes is very important.

Correspondence to: kpocepaviciute@gmail.com

Gauta 2021-05-07 